\title{
Prosodic Transcription of Standard Chinese and its Use in Teaching
}

\section{Zuzana POSPĚCHOVÁ}

Department of Asian Studies, Faculty of Arts, Palacký University Olomouc, Czech Republic zuzana.pospechova@upol.cz

\begin{abstract}
The present paper's main aim is to introduce a method of prosodic transcription (PTR) for Standard Chinese established by Oldřich Švarný in the background of the Czech Republic. It is used to describe suprasegmental features of Standard Chinese, namely the stress prominence and linear segmentation of sentences. PTR is applied in teaching Chinese prosody in the language courses around the Czech Republic. This paper also contains a short sample text, students' opinion on PTR and an outline of the use of PTR in academic research.
\end{abstract}

Keywords: Standard Chinese; prosody; PTR; Oldřich Švarný; teaching Chinese

\section{Povzetek}

Glavni namen članka je predstaviti metodo prozodične transkripcije (PTR) za kitajski jezik, ki jo je osnoval češki sinolog Oldřich Švarný. S to metodo je moč opisati suprasegmentalne značilnosti standardne kitajščine, kamor sodita stavčni poudarek in linearna segmentacija povedi. Na Češkem se PTR uporablja pri poučevanju kitajske izgovorjave. Članek predstavi kratko, vzorčno besedilo, prouči odzive in mnenja študentov ter poda oris, kako bi lahko prozodično transkripcijo uporabljali v akademskih raziskavah.

Ključne besede: standardna kitajščina; prozodija; PTR; Oldřich Švarný; poučevanje kitajščine

\section{Introduction}

This paper deals with a brief introduction and a simple description of the principles and methodology of prosodic transcription (PTR), which is used to transcribe Standard Chinese. The notational system of PTR was invented by a Czech sinologist, Prof. Švarný, based on the analysis of huge amounts of audio recordings of spoken Chinese.

This transcription enables us to describe prosodic features of modern spoken Chinese. It determines various levels of stress (tone) prominence of syllables (not only stressed and unstressed) and a linear segmentation of sentences (organization of syllables into more or less closely connected binary groups and groups of more than 
two syllables). The two prosodic characteristics constitute rhythmic structure of spoken Chinese. Their transcription helps beginner students to pronounce Chinese sentences more or less correctly, and has a considerable effect on the progress of their further studies. From the experience obtained in our department ${ }^{1}$, we can confirm the spoken realization of prosodically transcribed text is much more natural than the realization of the same text in pinyin or even in Chinese characters.

Finally, this paper also contains students' evaluation of the usefulness of PTR.

\section{Basic facts about Professor Švarný and his work}

In the introductory part of this paper, I would like to mention some basic facts about the outstanding Czech sinologist and phonetician Oldřich Švarný (1920-2011), whose lifelong research focused primarily on the sound structure of modern spoken Chinese and particularly on its prosodic (suprasegmental) features.

Švarný studied Chinese language and phonetics as a postgraduate at the Faculty of Arts of Charles University in Prague, where in 1952 he defended his thesis entitled Prosodic Characteristics of Syllable and their Modifications in the Continuous Speech. From 1951 he worked at the Oriental Institute of the Czechoslovak Academy of Sciences in Prague, where, among other projects, he established the Czech transcription of Standard Chinese, which continues to be used in press and fiction even today. In 1963 he defended his dissertation entitled Discussing the Concept of the Morpheme and Word in Modern Spoken Chinese. These two dissertations laid the basis for the entirety of his theoretical work.

All his life, he focused his research on phonological-syntactical analysis of frequent 'syllabosemems' (cf. morphemes), which became the basis for his lifelong work - $A$ Learner's Dictionary of Modern Chinese with sixteen thousand example sentences. He published individually or with his co-workers (his former co-workers Tang Yunling Rusková and Guang Minzhe were also one of his Chinese informants, later he was working together with his student and successor David Uher).

Švarný's suprasegmental theory based on PTR continues to be used at the Faculty of Arts at Palacký University Olomouc, and his works are still the basis for teaching Chinese prosody.

\section{System of prosodic transcription}

As mentioned above, the PTR of Chinese was one of Švarný's main research objectives. He was influenced by other related publications, such as Beginning Chinese (1963) by DeFrancis, Dictionary of Spoken Chinese (1966) and Fonetika kitajskogo jazyka (1972)

\footnotetext{
${ }^{1}$ Department of Asian Sudies, Faculty of Arts, Palacký University Olomouc, the Czech Republic
} 
by Spěšněv (Třísková, 2011, p. 45). Švarný and his co-workers worked on PTR for four decades and due to this long time development there are four different versions of the transcription. In spite of the fact that PTR underwent several evolutionary steps, the essential idea of all its versions is kept throughout without any substantial changes. The differences appear only in the graphic notational system.

During the whole time of development the main thought was to keep the transcription as simple as possible and express all the necessary prosodic features without becoming too cumbersome (Švarný, 1991b, p. 234). The sporadic alternations that were made to PTR in the following years were to utilize advances in technology, such as the change from hand-written to computer-typed transcription.

PTR's main aim is to capture prosodic features of spoken Chinese. These are essentially two; stress (tone) prominence and linear segmentation of sentences. As is well known, stress is one of the most important factors in Chinese, due to the fact that stress influences the modification of tones - they become weakened or emphasized. From an acoustic perspective stress prominence in Chinese can be manifested in the changes of pitch or syllable duration, or in a combination of both of these characteristics (Duběda, 2005, p. 55-56).

All rules of PTR described below were determined by Švarný on the basis of his long-term research work. The main method was a precise auditive analysis of thousands of of utterances nearing a spontaneous speech spoken by Chinese native speakers. This enabled him to develop a complete system of registering all relevant prosodic features as described below. However, this method was not determined purely by subjective auditive impression, it was also supported by objective measurements. In the late 1960's and early 1970's Švarný stayed in California at the phonetic laboratory of the University of Berkeley where he could process his speech recordings with machines, compiled graphs of a $F_{0}$ pitch. Having done so, he could support the adequacy of the set prosodic rules and the essential method of PTR.

Generally known prosodic terminology was slightly adapted for the use in European languages. Švarný preferred the term ictus to the term accent, because the quality of accent in European languages differs from the accent in Chinese, which is more flexible, e.g. it can move within a single word, changing the word's meaning at the same time. He also established a term for prosodic phrase: colon (pl. cola) and a term for prosodic word: segment. Because our research work employs the whole theory, we also accept these terms. However, the adaptation of this terminology is mostly relevant for researchers interested in Chinese prosody and PTR as a theoretical method. Students who use prosodically transcribed texts in their studies are unaffected by this term inconsistency.

PTR employs Chinese pinyin with slight modifications. Basic words and phrases in pinyin are given special marks that capture the "suprasegmental level of the utterances". In the process of transcribing, we mark rhythmical groupings of speech as first and tone syllable prominences as second. 
As for the rhythmical grouping, we distinguish three types of pauses: junctures, blank spaces and breaks (Švarný 2000, p. 150). Junctures are used between binary sequences and (or) odd syllables within the frame of rhythmical segments. This kind of pauses is marked by a hyphen between the sequences (e.g. chī-kăoyā) (Uher \& Švarný, 2014 , p. 11). Blank spaces are used between rhythmical segments which do not belong together and there is a short pause between them (e.g. qing-women-qu ${ }^{4}$ ta $^{1}$-jiā). Breaks indicate the boundaries of cola, the pause lasting approximately $3 / 4$ of a second. They are marked by common punctuation: comma, exclamation mark, point, or semicolon (e.g. zuótiān, zhāng-lao ${ }^{3}$ shī). Cola endings are also characterized by relative rising or relative falling intonations (Švarný, 1991b, p. 235). For foreign students it is difficult to master the prosodically correct pronunciation of relatively long cola at once. Instead, it is easier for them to acquire first the prosodically correct pronunciation of two to about four or five syllable long rhythmical segments and then join them together into cola (Švarný, 1991b, p. 236).

As for the tone syllable prominences, we distinguish stressed tone prominence, full tone prominence, weak tone prominence and atonicity. Stress tone prominence is always arse (ictus-bearing). Both full tone prominence and weakened tone prominence can be differentiated into arses (ictus-bearing syllables) and theses (non-ictus-bearing syllables). Atonic syllables are differentiated into neutralized syllables (with a slight residuum of tone) and toneless syllables (always without a tone) (Švarný, 2000, p. 150). Altogether we call this system as seven degrees of syllable prominence (Švarný, 1998, p. 24-25). Below you can see how these syllables are marked:

- $\quad$ stressed tone syllables: bold red font

- full tone ictus-bearing syllables: traditional tone mark

- full tone non-ictus-bearing syllables: traditional tone mark

- weakened tone ictus-bearing syllables: numerical indices ${ }^{1 / 2 / 3 / 4}$ (the number is determined by the tone)

- weakened tone non-ictus-bearing syllables: numerical indices ${ }_{1 / 2 / 3 / 4}$ (the number is determined by the tone)

- atonic neutralized syllables: no marking

- atonic toneless syllables: no marking

Appearing in this form, the transcription is simple and expresses all the necessary prosodic features. However, there is still a danger of confusion among full tone ictusbearing/non-ictus-bearing syllables, weakened tone ictus-bearing/non-ictus-bearing syllables and atonic neutralized/toneless syllables. For these purposes Švarný established implicit rules:

1. If a syllable is not marked in any way and occurs at the beginning of a rhythmical segment, it is automatically deemed as a weakened tone non-ictusbearing syllable. Marking by indices $1 / 2 / 3 / 4$ is waived in this case (Švarný, 1998, p. 26). 
2. For sequences of two, three and four full tone syllables within a frame of a rhythmical segment Švarný sets the default acronymic rule. This rule allows us to avoid another graphic representation of these syllables. In disyllabic rhythmical segments the ictus rests on the second syllable; in the trisyllabic and tetrasyllabic rhythmical segments there are ictuses on the first and last syllables (Švarný, 1998, p. 26-27; Švarný, 2000, p. 153).

3. The distinction between an atonic neutralized syllable and an atonic toneless syllable has to be inferred by the student himself (Švarný, 2000, p. 153).

If students follow all these linear rhythmical grouping and syllable prominence rules correctly, they will be able to produce Chinese utterances similar to the speech of native speakers.

However, in this theory there is a time handicap: to obtain a transcription, it is first necessary to have an audio recording of speech produced by a Chinese native speaker, which is then transcribed accordingly. Such transcription process itself is relatively lengthy and time-consuming, and efforts ${ }^{2}$ to come up with "universal prosodic transcription" which would allow linguists to transcribe texts according to the universal rules is understandable.

\section{Sample text and its audio recordings}

The sample text used here as a demonstration was taken from the Textbook of Chinese Conversation (Uher, 2012). This textbook is used for teaching beginner students in the first semester of Chinese studies at our department, thus the text is well known to them. The original text is in Chinese pinyin and the same text in PTR version is used from the second or third semester onwards. The text was transcribed according to an audio recording of native speakers. The sample text is as follows:

Chinese characters version:

昨天张老师请我们去他家吃饭。张老师的家很干净也很漂亮。张老师的饭 菜做得非常好。他的拿手菜是红烧肉。他做的红烧肉真棒。张老师还告诉 我们, 在中国的外国留学生常常说:不到长城非好汉。不吃烤鸭真遗憾。等 我以后到了北京, 我一定去看长城, 吃烤鸭。

Pinyin version:

Zuótian Zhāng lǎoshī qǐng wǒmen qù tā jiā chīfàn.

Zhāng lăoshī de jiā hěn gānjing, yě hěn piàoliang.

Zhāng lăoshī de fàncài zuò de fēicháng hăo.

Tā de náshǒucài shì hóngshāoròu.

\footnotetext{
${ }^{2}$ Represented by PhDr. Hana Trísková, Ph.D. from the Oriental Institute of the Academy of Sciences of the Czech Republic.
} 
Tā zuò de hóngshāoròu zhēn bàng.

Zhāng lǎoshī hái gàosu wǒmen, zài Zhōngguó de wàiguó liúxueshēng chángchang shuō:

Bú dào chángchéng fēi hăohàn.

Bù chī kăoyā zhēn yíhàn.

Děng wǒ yǐhòu dàole Běijīng, wǒ yídìng qù kàn chángchéng, chī kăoyā.

Prosodic transcription version:

Zuótiān, zhāng-lao ${ }^{3}$ shī, qǐng-women-qu ${ }^{4}$ ta ${ }^{1}$-jiā chī-fàn.

Zhāng-lao ${ }^{3}$ shī-d-jiā, hen ${ }^{3}$-gānjing yě-hen-piàoliang.

Zhāng-lao ${ }^{3}$ shī-d fàncài, zuò-d fēichang-hăo.

$T a^{1}$-d-náshoucài-shi hóng-shāo-ròu.

Tā-zuo ${ }^{4}-d$ hóng-shāo-ròu, zhēn-bàng.

Zhāng-lao ${ }^{3}$ shī, hái-gàosu-wo ${ }^{3}$ men, zai ${ }^{4}$-zhōngguo-d wàiguo-liúxueshēng

chángchang-shuō:

$\mathrm{Bu}^{2}$-dao ${ }^{4}$-chángchéng, fēi-hăohàn.

$\mathrm{Bu}^{4}$-chī kăoyā, zhēn-yíhàn.

Deng ${ }^{3}$-wo-yihòu dao ${ }^{4}$ le-běijīng, wo ${ }^{3}$-yíding qu4-kan chángchéng, chī-kăoyā.

A trial test was made to find out which production of these two text versions - pinyin and PTR - sounds more natural to a native speaker. Four anonymous beginner students were asked to read a sample dialogue in both pinyin and PTR versions and their reading was recorded. Two of them had read the pinyin version first and the PTR version second and two of them reversely. The recordings were carefully listened to by two native speakers who were neither informed about the existence of two different text versions nor about the overall aim of the trial test. Both of them proved the PTR version recordings to sound more natural.

One student audio recording and our findings were presented at the international conference on Chinese linguistics ${ }^{3}$ where the majority of participants were overseas Chinese native speakers and most of them considered our findings as valid.

The above mentioned facts lead us to believe that PTR could be helpful in teaching and studying Chinese and has a considerable effect on the quality and naturalness of speech of non-native speakers.

\footnotetext{
${ }^{3}$ The 27th North American Conference on Chinese Linguistics, University of California, Los Angeles, April 3-5, 2015.
} 


\section{Students' opinion}

Even though influence on the quality of speech has been proven, there is yet another important aspect of using PTR in teaching that is worth mentioning. Namely the students' opinion on PTR and its use in teaching: Is PTR user friendly or not?

To find out students' opinion about the use of PTR and its effects in the acquisition of Chinese pronunciation we have carried out a short survey. We gathered a total of 30 questionnaires, in which students answered 7 basic questions and expressed their own opinions about PTR. The following are the questions used in the survey, and their answers.

1. Was it hard for you to learn how to read prosodically transcribed text? (possible answers: hard, moderately difficult, easy)

None of the students chose the possibility 'hard', and $23 \%$ chose the possibility 'easy'. The largest group, $77 \%$ of students, chose the possibility 'moderately difficult'.

This is an answer to the most pressing question about PTR. The obtained result satisfactorily shows that PTR is manageable and not too complicated.

2. How do you appraise the PTR graphic notational system? (possibille answers: complicated, rather complicated, simple, rather simple)

None of the students chose the possibility 'complicated', while 'rather complicated' was chosen by $16 \%$ of students. $32 \%$ chose the possibility 'simple' and $52 \%$ the possibility 'rather simple'. If we count together the options simple/rather simple and complicated/rather complicated it comes to $84 \%$ and $16 \%$ respectively. In other words, PTR notational system is relatively simple for $84 \%$ of students.

It could be said that for the overwhelming majority of students (77\%) the difficulty of PTR is moderate and they are able to read prosodically transcribed text quite easily and without noticable troubles. The notational system is simple or rather simple for $84 \%$ of them. This shows that if students gain the insight into PTR, they will be able to use it easily and will find its notational system simple as well.

3. Do you think that reading from prosodically transcribed text sounds more natural than reading from pinyin? (possibile answers: less natural, more or less the same, more natural)

Results show that $13 \%$ of students chose the possibility 'less natural', $30 \%$ chose the possibility 'more or less the same', and $57 \%$ chose the possibility 'more natural'.

This shows that for more than half of the students reading from prosodically transcribed text sounds more natural than reading from pinyin. Nevertheless, an essential question on whether a beginner student is able to evaluate the naturaleness of speech and its slight nuances remains. It is well known that such judgements are rather difficult even for non-native teachers of Chinese. The best solution seems to be to rely on the opinion of native speakers. 
4. Does PTR have a positive effect on you at the beginning of your studies? (possibile anwers: no, rather no, yes, rather yes)

Only $3 \%$ of students chose the possibility 'no', $37 \%$ chose the possibility 'rather no', $40 \%$ chose the possibility 'yes', and $20 \%$ chose the possibility 'rather yes'. We can see the unequivocal answer 'yes' reaches $40 \%$ while the unequivocal answer 'no' has only $3 \%$. If yes/rather yes are counted together and no/rather no as well, the result is $60 \%$ and $40 \%$ in favour of the former.

That clearly shows that PTR has had a positive effect at the beginning of studies on $60 \%$ of students (in their opinion) and to us this is a very promising result.

5. What are the positives and negatives of PTR? (Answers were produced by the students.)

Negatives:

- confusing

- superfluous

We perceive that the existence of two text versions and two different notational systems could be somewhat confusing and PTR could be viewed as something superfluous, a "superstructure" of pinyin. The opinion will be one of the topics for future discussion between teachers and students.

Positives:

- easy learning

- correct realization of pronunciation and linear segmentation

- satisfactory understanding of the rhythm of speech and the placement of syllable prominences

- gradual improvement of speech

- step by step integration of PTR in teaching

As there are more positive than negative point stressed in the survey, this leads our team to think that PTR has a positive influence on beginner students, and that students are satisfied with its use in teaching.

6. Is PTR a benefit for beginner students? (possible answers: no, yes)

$12 \%$ of students chose the possibility ' $n o$ ' while $88 \%$ of them chose the possibility 'yes'.

This question differs from the previous question No. 4 (Does PTR have a positive effect on you at the beginning of your studies?) in that it refers to all students and is therefore supposed to be more objective. For the question No. 4, which was based on subjective experiences, $60 \%$ of students answered that PTR had a positive effect on their early Chinese language acquisition. The percentage of a positive answer in this latter, more objective question is almost $30 \%$ higher. $88 \%$ of students think that PTR is a benefit for beginners, and this makes our team believe that the positive influence and 
the effect of PTR is even wider than could be concluded from the asnwers on question No. 4.

7. What particular benefits or drawbacks are there to PTR? (Answers were produced by the students.)

Drawbacks:

- two versions of one text are confusing

This is the same problem as in the previous question No. 5 (What are the positives and negatives of PTR?), and will be also one of the topics for future discussion between teachers and students.

Benefits:

- learning to place stress on correct syllables, correct linear segmentation, correct syllable prominences

- easier orientation in a system of Chinese language

- understanding of natural pronunciation and its rules

- fixing of speech melody

- creation of correct habits in speech

- help in communication with native Chinese speakers

- "The speech sounds more chinese."

The last benefit that the speech sounds more Chinese could be a kind of principle of our work in the field of prosody. In general, our effort is focused on the achievement of correct production of suprasegmental units and to approximate it to a native speech. Table 1 shows results of the closed-ended questions:

Table 1: An overview of the closed-ended questions

\begin{tabular}{|l|l|}
\hline Question & Available answers \\
\hline
\end{tabular}

1. Was it hard for you to learn how to read prosodically transcribed text?

\begin{tabular}{|c|c|c|}
\hline hard & moderately difficult & easy \\
\hline $0 \%$ & $77 \%$ & $23 \%$ \\
\hline
\end{tabular}

2. How do you appraise the PTR graphic notational system?

\begin{tabular}{|c|c|c|c|c|}
\hline & complicated & rather complic. & simple & rather simple \\
\cline { 2 - 5 } & $0 \%$ & $16 \%$ & $32 \%$ & $52 \%$ \\
\hline
\end{tabular}

3. Do you think that reading from prosodically transcribed text sounds more natural than reading from pinyin?

\begin{tabular}{||l|c|c|c|c|}
\hline \multirow{2}{*}{} & less natural & more or less the same & more natural \\
\cline { 2 - 5 } & $13 \%$ & \multicolumn{2}{|c|}{$30 \%$} & $57 \%$ \\
\hline 4. Does PTR have a positive effect on you at the beginning of your studies? \\
\hline & no & rather no & yes & rather yes \\
\cline { 2 - 5 } & $3 \%$ & $37 \%$ & $40 \%$ & $20 \%$ \\
\hline
\end{tabular}




\begin{tabular}{|l|c|c|}
\hline \hline Question & \multicolumn{2}{|c|}{ Available answers } \\
\hline \hline
\end{tabular}

\section{Discussion}

The aim of this paper was to present PTR, a traditional method used for teaching Chinese language at the Department of Asian Studies in the Czech Republic, where it has been deep-rooted for several decades. Our experience show that there is still much effort to adapt it to the modern contemporary situation and continue the heritage of Oldřich Švarný. Our effort does not consist only in practical teaching, but there are also plenty of theoretical works using Švarnýs data and principles in academic spheres. By the application of PTR we are able to precisely describe all relevant prosodic features of modern spoken Chinese. From this point of view PTR is the first step for subsequent research. PTR enables us to count syllables of different stress prominence and average length of segments or cola, and analyze different rhythms contained in speech, their positions in a sentence and the number of ictuses.

We use the above mentioned methods for various types of research, e.g. comparing data gained formerly by Švarný with data gained currently in order to find out a potential language change, or in connection with sociolinguistics in order to find out suprasegmental differences between male and female speech.

PTR is used only with the Czech (and Slovak) language students of Chinese so far, however, its potential is thought to be wider. It is not a national transcription based and adapted on phonetic system of a particular language and is thus not restricted for usage in one language only. PTR could be an international system of transcription capturing prosodic features worldwide. As described above, PTR is warmly adopted by students, it helps them to produce Chinese sentences correctly. The first step of the process is reproduction and acquirement, the next step is imitation and the highest step is unsupported production.

\section{References}

Duběda, T. (2005). Jazyky a jejich zvuky: univerzálie a typologie ve fonetice a fonologii [Languages and their sounds. Universals and typology in phonetics and phonology]. Praha: Karolinum.

Švarný, O. (1952). Prosodic Characteristics of Syllable and their Modifications in the Continuous Speech. Unpublished manuscript. Prague: Charles University. 
Švarný, O. (1963). Discussing the Concept of the Morpheme and Word in Modern Spoken Chinese. Unpublished manuscript. Prague: Oriental Institute.

Švarný, O. (1991a). Prosodic Features in Chinese (Pekinese). Archív Orientální, 3, 234254.

Švarný, O. (1991b). Prosodic Features in Chinese (Pekinese): Prosodic Transcription and Statistical Tables. Archív Orientální, 3, 234-254.

Švarný, O. et al. (1998). Hovorová čínština v príkladech III. [Colloquial Chinese in Sentence Examples III.]. Olomouc: Palacký University.

Švarný, O. (1998-2000). Učební slovník jazyka čínského [A Learner's Dictionary of Modern Chinese]. 4 vols. Olomouc: Palacký University.

Švarný, O. (2000). Prosodical Transcription of Modern Chinese. Experimental Research and Teaching Practice. In Palková Z. (Ed.), Papers in Phonetics and Speech Processing (149-159). Frankfurt am Main: Hector Verlag.

Třísková, H. (2011). Prozodická transkripce čínštiny O. Švarného: čtyři historické verze [Oldřich Švarný's prosodic transcription of Mandarin: four successive versions]. Nový Orient, 4 (66), 45-50.

Uher, D. (2012). Učebnice čínské konverzace 2 [Textbook of Chinese Conversation]. Dosud nepublikovaný prototyp [Manuscript submitted for publication].

Uher, D., \& Švarný, O. (2014). Prozodická gramatika čínštiny. [Prosodical Grammar of Chínese]. Olomouc: Palacký University. 